\title{
Entrepreneurial Process Studies Using Insider Action Research: Opportunities \& Challenges for Entrepreneurship Scholarship
}

Kisito Futonge Nzembayie

Technological University Dublin, kisito.futongenzembayie@tudublin.ie

Anthony Paul Buckley

Technological University Dublin, anthony.buckley@dit.ie

Follow this and additional works at: https://arrow.tudublin.ie/buschgraart

Part of the Business Commons

\section{Recommended Citation}

Futonge Nzembayie, K. \& Buckley, A.P. (2020). Entrepreneurial Process Studies Using Insider Action Research: Opportunities \& Challenges for Entrepreneurship Scholarship. Management Review doi.org/ 10.1111/emre.12422

This Article is brought to you for free and open access by the Graduate Business School at ARROW@TU Dublin. It has been accepted for inclusion in Articles by an authorized administrator of ARROW@TU Dublin. For more information, please contact arrow.admin@tudublin.ie, aisling.coyne@tudublin.ie,gerard.connolly@tudublin.ie.

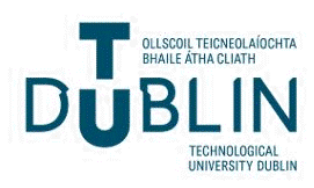


See discussions, stats, and author profiles for this publication at: https://www.researchgate.net/publication/343421775

\section{Entrepreneurial Process Studies Using Insider Action Research: Opportunities \& Challenges for Entrepreneurship Scholarship}

Article in European Management Review · August 2020

DOI: $10.1111 /$ emre.12422

CITATIONS

0

2 authors:

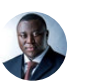

Kisito Futonge Nzembayie

Technological University Dublin - City Campus

5 PUBLICATIONS 21 CITATIONS

SEE PROFILE
READS

75

Anthony Buckley

Technological University Dublin - City Campus

12 PUBLICATIONS 36 CITATIONS

SEE PROFILE

Some of the authors of this publication are also working on these related projects:

Digital Entrepreneurship: A Real-time Study of the Digital Entrepreneurial Process View project

Digital Entrepreneurial Marketing \& the Role of Algorithmic Agencies: Rethinking Customer Centricity in New Venture Creation View project 


\title{
Entrepreneurial Process Studies Using Insider Action Research: Opportunities \& Challenges for Entrepreneurship Scholarship
}

- Corresponding/First author: Kisito Futonge Nzembayie (https://orcid.org/0000-00033234-046)

- Co-author: Anthony Paul Buckley

- Affiliation of all authors: College of Business, Technological University Dublin

- Email: kisito.futongenzembayie@tudublin.ie

\section{Recommended Citation}

Nzembayie, F. K., and Buckley, A. P. (2020) Entrepreneurial Process Studies Using Insider Action Research: Opportunities \& Challenges for Entrepreneurship Scholarship. European Management Review, https://doi.org/10.1111/emre.12422.

\begin{abstract}
This paper examines the opportunities and challenges of adopting Insider Action Research (IAR) in entrepreneurial process studies. It employs a critical reflexive and narrative approach in examining our own lived experience in a real-time digital entrepreneurial journey spanning three years while triangulating it with experiential knowledge in another role as dissertation supervisors. Our live case illustrates that IAR, when it combines reflective practice, cooperative inquiry and design science, represents a suitable but under-exploited methodology for entrepreneurship scholarship. We build on this knowledge to offer a model for incorporating this methodology in entrepreneurship research and education. Consequently, we contribute towards responding to the need for phenomenon-methodology fit in the discipline. Ultimately, the paper's value lies in its effort towards resolving the seemingly perennial question regarding the legitimacy of entrepreneurship as a distinctive domain of scholarship.
\end{abstract}

Keywords: Entrepreneurial process, Insider Action Research, Entrepreneurship Scholarship 


\subsection{INTRODUCTION}

Attaining good quality organisational research partly hinges on achieving phenomenonmethodology fit. Phenomenon-methodology fit is broadly defined as ensuring logical consistency between the aim of the research and its design choices, as well as prior research and contribution to theory and practice (Edmondson \& McManus, 2007). In the entrepreneurship context, Davidsson (2016) emphasises the need for logical consistency by stating that poor research practices include addressing qualitative problems with mainly quantitative methodologies and vice-versa. Research, therefore, has to let the phenomenon and its corresponding research question, dictate the appropriate design choices, and not the other way round (Bouchard, 1976). Similarly, entrepreneurship education requires a practice-based pedagogical methodology, which is consistent with the pragmatic nature of the phenomenon.

The entrepreneurship phenomenon has been described as a process of 'ongoing creative organising' (Johannisson, 2011). This process often involves tensions between order creation and the uncertainty of entrepreneurial emergence. Order creation begins as the envisioning of future outcomes based on externally enabled new venture ideas (Davidsson, 2015). Meanwhile, tensions manifest as entrepreneurs commit time and effort in translating their vision into reality through action. Hence, entrepreneurial action is usually defined by the situatedness of uncertainty perceived and the willingness to bear uncertainty (McMullen \& Shepherd, 2006). The dialogue that ensues from the tensions often ensures that the entrepreneurial journey unfolds as a series of non-linear events. There are several initiatives for responding to the somewhat chaotic nature of the phenomenon in teaching and research.

Given the nature of the phenomenon, several scholars argue that it hardly lends itself to methodologies developed for smooth continuous processes (Bygrave, 2007). Accordingly, Wiklund et al. (2011) argue for a phenomenon-based view of entrepreneurship research, which extends the study of entrepreneurship into new domains. With this view, entrepreneurship is a 
phenomenon defined by change, newness and development that transcends organisational contexts (Welter, 2011). As a dynamic phenomenon, studies need not merely focus on 'what is', but 'what happens' with sensitivity to time (Roe, 2008). Hence, calls for more attention to temporality in entrepreneurial process studies have been made (McMullen \& Dimov, 2013). To capture a true representation of the phenomenon as it emerges over time, research and education must be immersed in the 'swampy lowlands' of practice (Schon, 1987), observing events as they happen (Davidsson et al., 2011), while introspectively and retrospectively analysing them to learn and unearth the causal mechanisms shaping events at various temporal phases. Accordingly, Johannisson (2018) argues that to effectively study the phenomenon of ongoing creative organising, researcher and entrepreneur identities need to be merged. Thus, methodologies built on a functionalist paradigm appear ill-equipped for the task, given their emphasis on detached observation and back casting from cross-sectional accounts of past events. Yet, these methodologies remain dominant in the entrepreneurship discipline, thereby contributing to the continuous challenge of its legitimacy as a bona fide domain of scholarship (Wiklund et al., 2011; Landstrom et al., 2016).

Therefore, this paper examines the opportunities Insider Action Research (IAR) presents as a methodology for studying the entrepreneurship phenomenon. It then offers a model for merging IAR with the entrepreneurial processes to form symbiotic relations of scholarship and new venture creation. Further, we identify and discuss possible challenges involved in using this approach and the mechanisms for navigating them. We do so by reflecting on our own 'insider-acted' live case in a digital entrepreneurship context. We triangulate our experiences in another role as dissertation supervisors in identifying the opportunities and challenges that IAR offers for generating insights on entrepreneurial journeys that is beneficial to theory and practice. As such, we respond to the need for interestingness in entrepreneurship scholarship by meeting the needs of multiple stakeholders (Frank \& Landstrom, 2016). 
We begin by exploring a conceptual understanding of the entrepreneurship phenomenon and relevant state-of-the-art debates regarding scholarship. We then examine IAR and establish key linkages that make it a suitable methodology for entrepreneurship research and education. Finally, we leverage our experiential knowledge in two insider-acted cases of digital entrepreneurship, as the basis for developing an integrative model for application in entrepreneurial process studies.

\subsection{ReSEARChING THE ENTREPRENEURSHIP PHENOMENON}

Conceptually, entrepreneurship has been summed up as a process of emergence, leading to new economic outcomes (Wiklund et al., 2011). This process, which begins with an act of human volition, involves the discovery or creation and exploitation of opportunity to create future goods, services and new organisations as outcomes (Shane \& Venkataraman, 2000). Entrepreneurial opportunity hereby refers to new venture ideas and their related external enablers, while exploitation relates to entrepreneurial action in new venture creation (Davidsson, 2015). At the micro-level of emergence, entrepreneurial actors interpret external enablers which exist at the macro level and translate them into new venture ideas which are metaphors for new market offerings. Only by committing time and effort through action in new venture creation, can entrepreneurial actors transform new venture ideas into new market offerings, in a process laden with various forms of uncertainty.

The transformation of ideas into outcomes is, therefore, the epicentre of new venture creation. In other words, entrepreneurship does not happen without action. Action in new venture creation is a product of the amount of uncertainty perceived and the willingness to bear uncertainty (McMullen \& Shepherd, 2006), thereby making the cognitions of the entrepreneur an essential component in understanding the micro-foundations of new venture emergence. It thus highlights the need to study the thought processes of entrepreneurs as they face and react 
to the situatedness of uncertainty in the process of emergence. Hence, Johannisson (2011) describes the entrepreneurial journey as a process of ongoing creative organising in an attempt at order creation. Since entrepreneurship is bound to unravel differently across contexts, the vicissitudes that befall various journeys can hardly be known in advance, thereby requiring ongoing reaction to the chaos of what is a highly dynamic process.

Not surprisingly, some of the main theoretical contributions of the discipline have attempted to describe this dynamism by offering explanations for the actor-derived causal mechanisms that shape the phenomenon. Pragmatic entrepreneurship theories such as effectuation (Sarasvathy, 2001) and bricolage (Baker \& Nelson, 2005), as well as practitioner models such as the lean start-up (Ries, 2011) and design thinking, espouse experimentation, affordable loss and flexibility (Fisher, 2012) as actor-derived causal mechanisms that explain the process of ongoing creative organising. These theories depart from a causation approach and its neoclassical origins, which depicts a linear process of entrepreneurial emergence, marked by strict adherence to decision making, planning and execution. Causal theories emphasise intentionality, objective opportunity identification and evaluation, planning and resource acquisition, and the deliberate exploitation of opportunity as defining characteristics (Fisher, 2012). Causal theories have attracted much criticism because they run contrary to underlying assumptions of uncertainty, which most scholars agree is a cornerstone of all entrepreneurship assumptions (Shane \& Venkataraman, 2000; McMullen \& Shepherd, 2006).

The above-explored pragmatic theories on the other hand, have been highly correlated to situations of uncertainty and resource constraints - whereby, these conditions provide catalysts for ongoing creative organising. Hence, they have proven invaluable in offering theoretical and practical explanations for actor-derived causal mechanisms of the entrepreneurial process. Coupled with this pragmatic philosophical orientation, entrepreneurship is conceived as a science of the artificial (Venkataraman et al., 2012) - 
meaning, it studies worlds that can be created through human design (Simon, 1996). Indeed, multiple artifacts are outcomes of the entrepreneurial process at various temporal phases. At nascent phases, expressed new venture ideas are artifacts of entrepreneurial conceptualisation, while at subsequent phases, new products and services, as well as new organisations and realised business models, are mature artifacts emerging at subsequent stages of the process (Selden \& Fletcher, 2015). Scholarship may therefore leverage various artifact-demarcated phases of emergence to define the objects of research projects and their related lines of inquiry.

Given the action-artifact nexus and the inherent uncertainty that defines the phenomenon, the ontological and epistemological orientation of research and education is best framed against Aristotelian phronesis - which is knowledge gained through praxis (Eikeland, 2006). Accordingly, understanding the phenomenon across contexts appears logically consistent with methodologies which are immersive, iterative and action-oriented in nature, ideally involving the merging of researcher and entrepreneur identities (Johannisson, 2018). Yet, such methodologies remain under-exploited in the discipline, crowded out by traditional modes of inquiry built on a functionalist paradigm - where processes are assumed to be stable and smooth, and theory testing is central to research (Landstrom et al., 2016). Consequently, Bygrave (2007) bemoans the state of research by stating that the entrepreneurship paradigm is 'becoming increasingly aloof from any nexus with practical utility'. Further, he criticises the discipline for squandering the opportunity to develop a new design paradigm that is more consistent with a profession than pure science. Likewise, Sarasvathy and Venkataraman (2011) call for an 'Entrepreneurial Method' whose mechanisms are action, reaction, transformation and explicit co-creation. Such a method will help attain logical consistency with the phenomenon and contribute towards resolving questions on the discipline's legitimacy as a distinctive domain of scholarship. 
However, achieving logical consistency between the entrepreneurship phenomenon and methodology is often plagued by known challenges. To accurately learn and theorise how and why the entrepreneurial journey emerges over time, a longitudinal approach is required which sequentially documents the process in real-time from its very inception and develops a comprehensive process narrative (McMullen \& Dimov, 2013). Real-time longitudinal studies help overcome issues of hindsight bias, selective recall and picking winners, with the potential for misleading research conclusions. Notwithstanding, known challenges of longitudinal research designs often imply that they are less feasible within the constraints of short-term academic research. Hence, researchers may be driven to take the less risky functionalist approach to research, evident in more conventional research methodologies that emphasise theory testing and filling ever tinier gaps in knowledge. As Davidsson (2016) notes, gearing research towards filling ever tinier gaps is far from optimal, as it adds very little to our understanding of the causal mechanisms that give shape to the entrepreneurial process.

\subsubsection{Entrepreneurship Education \& the Phenomenon}

It appears the problems of researching the phenomenon and educating students are two sides of the same coin. The discipline still struggles for legitimacy owing to the borrowing of methodologies ill-suited to developing entrepreneurial competence in students. As Cobla and Katz (2012) observe, the entrepreneurship phenomenon is defined by action, yet the discipline ironically pays scant attention to studying action. Entrepreneurship Education (EE) has expanded rapidly over the last decade, as evidenced by the numerous university programmes on entrepreneurship. Its focus has been on changing attitudes and motives to impact students' propensity and intentionality for real-world action. Hence, the emphasis has been on developing entrepreneurial mindsets with the hope that it influences action at a later stage in life. Research is still emerging regarding the extent to which such education impacts on the level of graduate entrepreneurship, or whether it enables graduates to become more effective entrepreneurs 
(Pittaway \& Cope, 2007). As intent is not the same thing as behaviour, there has been a recent push towards practice-based education (Neck \& Greene, 2011). However, some attempts at promoting education that ends in entrepreneurial behaviour, have resulted in some programmes merely becoming factories for producing start-ups (Honig, 2004).

Accordingly, Fayolle (2013) proposes a way forward in the form of key recommendations for entrepreneurship education. Firstly, EE should focus on entrepreneurship competences that result in relational, conceptual, organising and commitment capabilities. Instead of merely rendering programmes factories for producing start-ups, they should also be designed to produce entrepreneurs capable of thinking, acting and making decisions under uncertainty, in a wide range of situations and contexts. Therefore, principles of pragmatic theories such as entrepreneurial bricolage, effectuation and design-based models should be incorporated in the formulation of an 'Entrepreneurial Method' (Sarasvathy \& Venkataraman, 2011). Secondly, reflective practice and critical approaches are recommended in research and education (Schon, 1984). In sum, breaking down the silos between thinking and acting, the world of academia and that of practice, and between disciplines looking at EE, is deemed an ideal path.

However, calls for action-based approaches to entrepreneurship scholarship are not new (Rasmussen \& Sørheim, 2006). The problem partly appears to lie in the fact that methodologies for promoting action-based theories of education remain under-explored and require crossdisciplinary dialogue (Neck, Greene \& Brush, 2014). Consequently, Neck and Greene (2011) highlight the need for a practice-based methodology which goes beyond understanding, knowing and talking, and demands using, applying and acting. Some of its tools should include starting a business as part of coursework, design-based thinking and reflective practice. 
Similarly, in research projects, research designs that leverage new venture ideas as design artifacts to be enacted and studied in real-time, are considered logically consistent with capturing and learning about the entrepreneurial process (Dimov, 2016). Accordingly, we examine the opportunities and challenges that Insider Action Research (IAR) presents as a methodology for entrepreneurship scholarship.

\subsection{Insider ACtion Research \& Phenomenon Fit}

To understand IAR, one must begin with a brief overview of action research. Action research (AR) is a family of practices (Reason \& Bradbury, 2008) that aim to produce 'actionable knowledge' (Argyris, 1996) - defined as knowledge that is relevant to both theory and practice. It is an emergent process of co-inquiry involving the integration of behavioural science knowledge with existing organisational knowledge in solving real-world challenges (Shani \& Pasmore, 1985). AR follows a cyclical inquiry method of planning, taking and evaluating action. Its epistemology is rooted in multiple philosophical traditions, of which pragmatism and critical realism often appear complementary and recurrent (Johansson \& Lindhult, 2008). Given its philosophical orientation, AR combines what has been termed an 'extended epistemology', which features experiential, presentational, propositional and practical knowing (Heron \& Reason, 2008). Accordingly, knowledge production and acquisition begin with direct experiences in the world. Meanwhile, critical reflexivity plays the dual role of rigorously translating real-world experiences into valid academic knowledge, as well as promoting learner-driven learning. Given its emphasis on direct engagement and emergent inquiry, action research epistemology appears logically consistent with studying the entrepreneurial process.

However, being a family of practices which share core similarities but retain their distinctive emphasis, it remains unclear which modalities of AR may be adopted in studying 
the entrepreneurial process. Since understanding the causal mechanisms driving entrepreneurial processes calls for the merging of researcher and entrepreneur identities (Johannisson, 2018), Insider Action Research (IAR) appears primed for the task (Coghlan, 2019) - especially when it subsumes the modalities of Reflective Practice (Schon, 1983), Cooperative Inquiry (Heron \& Reason, 2006) and Design Science in a multimethod framework (Nzembayie et al., 2019). By 'insider-acting' the entrepreneurship phenomenon, researchers and students assume entrepreneur identities in a dual role. Since IAR subscribes to the philosophy that 'all good research is for me, for us and for them' (Reason \& Marshall, 1987, p. 112), it has the benefit of addressing the needs of multiple stakeholders in one methodology.

\subsubsection{Reflective Practice \& Cooperative Inquiry in IAR}

Traditionally, Reflective Practice (RP) is indispensable to the first-person inquiry and learning dimensions of IAR. First-person inquiry assists in providing an accurate account of events in real-time, while standing back from them to uncover key insights through critical reflection. It allows the researcher to live life as inquiry, thereby maintaining curiosity through 'inner and outer arcs of attention' about events in the entrepreneurial process, and their role in shaping action, interaction and non-action (Marshall, 1991). Thus, through RP, researchers and students can learn and reveal fine-grained details of the entrepreneurship phenomenon from experience, and the causal mechanisms driving it at various temporal phases of emergence (McMullen \& Dimov, 2013). Such in-depth insights can hardly be achieved merely through detached observation and back-casting in search of ex-post insights, as consistent with most conventional and functionalist methodologies of teaching and research.

Secondly, since entrepreneurship is an inherently collaborative phenomenon, it achieves logical consistency with the nature of co-inquiry which IAR espouses. Hence, core components of Cooperative Inquiry (CI), traditionally form the critical second-person dimensions of IAR. Cooperative Inquiry emphasises 'research with people rather than on people' (Heron \& Reason, 
2006). Accordingly, entrepreneurship researchers and students see collaborators in new venture creation as democratic partners in the co-generation of knowledge and learning. Indeed, entrepreneurship theories such as effectuation, depict entrepreneurship as new venture cocreation, with collaborators entering the process to provide new means that advance the process (Sarasvathy, 2001). In blending researcher and entrepreneur identities through IAR, experiences in new venture offer multiple opportunities for the contemporaneous co-creation of economic value and co-generation of valid academic knowledge, as well as the development of critical competences in learners for leading new venture creation.

\subsubsection{Design Science in IAR}

Meanwhile, Design Science (DS) and its corresponding Design Research (DR) approach, combines both first-person and second-person inquiry, but places emphasis on the design artifact and its potential for knowledge on design processes. Its research outcomes are made manifest in design constructs, models and frameworks (Mach \& Smith, 1995). Its incorporation in an IAR methodology framework (Coghlan, 2019, p. 71-72) perhaps offers the most potential for studying the entrepreneurial process in a practice-based approach (Nzembayie et al., 2019). As noted, the entrepreneurship phenomenon involves acting to translate new venture ideas into new market offerings (Davidsson, 2015). Hence, it lends itself to DS, wherein new venture ideas become design artifacts to be enacted and studied in realtime through the generative power of recursive action (Dimov, 2016). As such, researchers or students can purposely enact and align the entrepreneurial process with research or study goals, with the dual benefit being the creation of academic knowledge and the development of entrepreneurial capabilities (Coghlan \& Shani, 2008). Further, design science offers a bidirectional approach where theory informs design and design combines with theory to generate new theories or evaluate existing ones. 
As Berglund et al. (2018) observe, design science can highlight ways in which existing theories of entrepreneurship are processually incomplete. It also offers enormous potential for making substantive contributions which manifest in the synthesis of a body of work through a literature review, whose explicit goal is the formulation of design propositions (Van Burg \& Romme, 2014). With this approach, the theoretical basis of design principles which exist among entrepreneurial practitioners such as the lean startup model can be evaluated. Researchers could also seek to reconstruct the social mechanisms and theories of action assumed in non-causal entrepreneurship theories such as effectuation and bricolage (Berglund \& Korsgaard, 2017). Further, the real-time exploration of the entrepreneurship phenomenon can be carried out with a view towards formulating new design principles that are robustly grounded in theory. Hence, an abductive approach to generating inferences will prove useful in eschewing the pitfalls of naïve empiricism. By cycling back and forth between experience and a body of entrepreneurship theories, abductive inference offers the basis for grounding explanations of the causal mechanisms driving entrepreneurial processes across contexts, as well as rendering critical reflection more rigorous.

Together, the above-explored modalities of AR which are subsumed in an IAR methodology framework, offer an essential toolkit for entrepreneurship education and research. We examine two cases in a digital entrepreneurship context subsequently that illustrate the opportunities for embracing IAR as a mode of entrepreneurship scholarship.

\subsection{INSIDER-ACTING DIGITAL ENTREPRENEURSHIP}

The first case (henceforth Case 1) is an insider-acted case of Pure Digital Entrepreneurship (PDE), while the second case (henceforth Case 2) involves Hybrid Digital Entrepreneurship (HDE). By insider-acting, we mean the merging of researcher or student and entrepreneur identities in the real-time enactment of entrepreneurial emergence. Examining the 
digital entrepreneurship phenomenon is a nascent domain of entrepreneurship scholarship and therefore, perfectly primed for a phenomenon-driven mode of inquiry (Edmondson \& McManus, 2007; Nambisan, 2016). It is, therefore, important to begin by briefly defining what digital entrepreneurship is.

\subsubsection{The Digital Entrepreneurship Phenomenon}

Digital entrepreneurship exists as two main typologies - PDE and HDE. PDE is entrepreneurship in which digital artifacts and digital platforms constitute the new venture ideas and market offerings (von Briel et al., 2018; Nzembayie et al., 2019). The technological basis of this form of entrepreneurship has several implications for the entrepreneurial process. Digital artifacts are 'quasi-objects' existing as lines of code or bits of data (Ekbia, 2009). Their software basis renders them reprogrammable, editable and instantly distributable over the vast expanse of cyberspace (Kallinikos et al., 2013). Hence, entrepreneurial ideas purely based on digital artifacts result in less-bounded entrepreneurial processes in terms of their temporal and spatial structures, with entrepreneurial agency becoming diffused among dynamic co-creators (Nambisan, 2016). Digital technology therefore results in the democratisation of PDE, whereby actors opt into the digital entrepreneurial process on their own terms with its corresponding leadership challenges (Aldrich, 2014). Further, PDE resides in the context of what is termed 'economics of bits' (Brynjolfsson \& McAfee, 2014) - marked by the creation of non-rival market offerings which do not get depleted when consumed. Hence, digital entrepreneurial market offerings may be expensive or inexpensive to create, but certainly cheap to replicate. It results in a form of entrepreneurship that lends itself to extreme flexibility and experimentation as ideas can be enacted and re-enacted in multiple iterative cycles of experimentation, in search of scalable business models. Examples of new ventures that emerged under this form of entrepreneurship are Facebook and Twitter. 
Meanwhile, Hybrid Digital Entrepreneurship (HDE) is entrepreneurship in which digital artifacts, physical artifacts and tactile services, are equally and mutually important in new venture ideas. In cases where software and hardware are tightly coupled and equally dependent, the physical and tactile elements in new market offerings often reintroduce varying constraints of spatial and temporal boundedness in the entrepreneurial process - which is more reflective of traditional new venture creation (von Briel et al., 2018). Nevertheless, it is assumed that the software and network-based dimensions of HDE (i.e., creation of digital artifacts) will offer some of the benefits of extreme flexibility and experimentation which are consistent with PDE. An example of a new venture that emerged under HDE is Fitbit and its smartwatch wearable technology market offering.

Ultimately, when digital artifacts form the core of new venture ideas and market offerings, entrepreneurial processes can be more feasibly and longitudinally insider-acted within the constraints of short-term academic research (Nzembayie et al., 2019). As such, new venture ideas based on the creation of digital platforms and software-based offerings can easily become design artifacts, enacted and studied in real-time. Some of these ideas can also be enacted with minimal resources, allowing researchers to engage in live projects involving entrepreneurial bricolage and effectual experimentation (Sarasvathy, 2001; Baker \& Nelson, 2005).

Therefore, insider-acting a PDE or HDE journey more readily allows researchers and students to double as entrepreneurs initiating and leading a nascent process of new venture creation in search of scalable outcomes. Nascent or early-stage entrepreneurship needs to be captured from inception and recorded as it happens for learning and causal explanations to be solidly grounded (Davidsson et al., 2011). As von Briel et al. (2018) suggest, PDE potentially results in much shorter early-stage entrepreneurial processes than traditional forms of entrepreneurship. We subsequently examine lived experiences in a doctoral and master's 
research and learning context, to illustrate the opportunities and possible challenges of embracing IAR as a methodology for entrepreneurship.

\subsubsection{Two Cases Using IAR in Digital Entrepreneurship Research \& Education}

Case 1 relates to our own longitudinal doctoral study in a PDE context spanning a little over three years. Meanwhile, Case 2 originates from our role as supervisors facilitating an MBA dissertation in a Hybrid Digital Entrepreneurship context spanning over six months. The MBA dissertation had an innovative consultancy orientation to research whereby the primary focus was to encourage learning that results in knowledge the student could applying in developing and scaling their start-up. Thus, dissemination was not a priority for Case 2. Table 1 briefly summarises both projects.

\section{Insert Table 1 Here}

Table 1. Brief Summary of Two Cases Insider-Acting Digital Entrepreneurship

In Case 1, one of us insider-acted a PDE journey in a holistic change programme, while the other played the role of a 'critical friend' (Herr \& Anderson, 2014). Holistic change programmes are considered ideal for observing the entrepreneurial journey in an entire stage of emergence, with the whole process coming under observation. They are therefore more suited to doctoral studies which typically span a couple of years. Meanwhile, Case 2 was a limited change programme which allowed our student to examine a nascent entrepreneurial process, with a focus on searching for a scalable business model. It was a core component of the student's MBA education with less emphasis on dissemination. By triangulating our experiences in both roles, we learn a great deal about the opportunities and challenges of adopting an IAR approach in entrepreneurship scholarship, which we discuss subsequently. 


\subsection{OpPORTUNities \& Challenges OF USING IAR}

We examine IAR opportunities against the backdrop of well-known challenges of the methodology. As Coghlan (2007) observes, IAR involves managing three interlocking challenges. The first relates to preunderstanding, which comes from being close to the setting while at the same time, distance is required for observations to be critical. Thus, preunderstanding can inhibit critical reflexivity, which is needed for learning to occur. Secondly, role duality is a challenge which comes from merging researcher or student and entrepreneur identities. Role duality results in ambiguities regarding research, learning and practice. Thirdly, organisational politics in multiple manifestations, call for skilful and tactful management. Researchers and students need to balance their future ambitions and the quality of their IAR projects.

\subsubsection{Opportunities for Research \& Practice-Based Education}

As both cases illustrate, IAR contributes towards the development of entrepreneurial capabilities beneficial to practitioners and their communities of practice. These capabilities form the basis of future organisational core competencies that enhance a new venture's potential for improved performance. Further, researchers engage in third-person knowledge production as they ground entrepreneurial practice in theory, resulting in the production of design-based knowledge, as well as the application and critique of extant theories. Through the IAR process, existing theories become enriched and expanded in different contexts, while new avenues for research are identified and highlighted. Case 1 is a doctoral study which allowed one of us to examine his practice as a digital entrepreneur in EdTech, arriving at much-needed clarity on current and prior experiences in his industry. At the end of the project, he captures the transformative impact the process has had on him in the following reflective excerpt: 


\begin{abstract}
...despite many successes as a portfolio digital entrepreneur, I suffered from impostor syndrome and had self-doubts given the accidental nature of my entrepreneurial entry. By grounding my thinking in theory, I have emerged with a clearer understanding and articulation for what seems to work or does not work, when, how and why. When I began this journey, I was unsure of the lessons which may arise along the way. However, I have learned that the research process is an entrepreneurial process, and only by taking action and reflecting on it, can critical insights emerge...the wealth of theoretical knowledge that the research has compelled me to review has provided the vocabulary for articulating my tacit knowledge and actions. I have learned that articulating one's thoughts is essential for crystallising understanding. In many ways, it is rather emancipatory. Hence, I continue to muse over the genius of Schon (1984, p. 243) who identified the problem of accidental but successful entrepreneurs like myself. He notes that practitioners do reflect in action but seldom reflect on their reflection in action, thereby making their knowledge tacit and difficult to articulate even to themselves. Schon argues that the lack of articulation means that practitioners struggle to translate their tacit knowledge into efficient and effective strategies which they or others can adopt and formalise. What an epiphany! Indeed, through a research process that allowed me to live, reflect and articulate my actions in the world, an unprecedented clarity and direction has emerged.
\end{abstract}

Since a central thesis in practice-based entrepreneurship education is the development of entrepreneurial mindsets and competences, Case 1 reveals that IAR is well-positioned to meet such individual learning needs as highlighted by the reflective excerpt. As such, IAR is a learning methodology which can be applied in structuring practice-based entrepreneurship education. Given our research interests, most of our undergraduate and master's students often opt for entrepreneurial projects that have digital artifacts such as mobile apps and digital platforms as new venture ideas and new market offerings. These are based on realistic ideas which they intend to scale after graduation. The projects present unique opportunities for handson learning, leading to the validation or falsification of new venture ideas.

Further, action design-based projects often offer fertile ground for IAR dissertations and learning projects. As the two cases suggest, multiple learning outcomes and research objectives can be met as students work on projects which may very well form core projects in IAR dissertations (Zuber-Skerrit \& Perry, 2002). In the process, they acquire capabilities in bearing and managing uncertainty in the ongoing process of creative organising. As we reflect on Case 1 and our experiences supervising Case 2 and others, we note that there is a tendency to underestimate the importance of good collaborative leadership skills that prevents premature new venture discontinuation. We learn that collaborative leadership skills combine with selfregulatory cognitive processes as actor-derived mechanisms driving performance. Through 
critical reflexivity and action in new venture creation, even experienced portfolio entrepreneurs as in Case 1, learn more about how prior successes were achieved. As such, they are in a better position to translate tacit knowledge into a communicable form for dissemination. Ultimately, using IAR contributes towards allaying Bygrave's (2007) concerns that the entrepreneurship discipline is becoming aloof from any nexus with practical utility. Likewise, we address the need for interestingness in entrepreneurship scholarship with its multi-stakeholder focus (Frank \& Landstrom, 2016).

\subsubsection{Model for Practice-Based Entrepreneurship Research \& Education}

To take advantage of the opportunity IAR presents for research and education, we develop a dual-purpose model for guiding research and education. It builds on Coghlan and Shani's (2008) framework for developing organisational capabilities through IAR. Our model combines IAR and the entrepreneurial process, in concomitantly meeting the need for academic knowledge production and the development of entrepreneurial competences through practicebased learning - see Figure 1 subsequently. As the model illustrates, the entrepreneurial journey and the IAR process emerge against a backdrop of an external environment and its potential external enablers (Davidsson, 2015). Entrepreneurs translate external enablers into ideas that trigger new venture creation. In their dual role as researchers, they also identify and develop knowledge production needs against enablers of the academic and societal environment.

\section{Insert Figure 1 Here}

Fig. 1. Model of Practice-Based Entrepreneurship Education \& Research

As both cases indicate, clarifying research and learning needs, as well as the future venture's needs, begins an evaluation phase prior to insider-acting both processes. Together, the two mutually dependent sub-processes form symbiotic relations of new venture co-creation and new knowledge co-generation (Nzembayie et al., 2019). Consequently, the needs of multiple stakeholders are met in one methodology. 


\subsubsection{Navigating Challenges of Role Duality Against Entrepreneurial Uncertainty}

However, as with almost every opportunity, there are challenges to be overcome. As noted, role duality makes the IAR research process quite demanding. When coupled with the inherently uncertain nature of entrepreneurial processes, one can understand why some researchers may prefer a less risky option. As both cases reveal, there is the ever-present threat of premature project discontinuation due to the exit of key collaborators. In short, the entrepreneur is not fully in control since the democratisation of entrepreneurship renders mission-critical, but oftentimes loosely connected co-creators critical in deciding an emerging new ventures fate. In both cases, there were significant moments when new venture creation stalled owing to the exit or lack of commitment of key collaborators. Consequently, the IAR research process was plunged in limbo as alternatives were being considered. This was, without doubt, a stressful scenario for the researchers. However, it is exactly such scenarios that reveal the pressures entrepreneurs put themselves through on a tumultuous journey while exploiting opportunities for learning. By reflecting on the emotional stress, researchers are able to reveal data of interiority (Coghlan, 2019) that capture entrepreneurial thought processes under uncertainty. Further, the action-specific reactions to uncertainty offer valuable lessons on the capabilities needed to navigate such moments of high emotional intensity and the cognitive overloads that come with it.

Given that entrepreneurship studies often preach risk and uncertainty as an inherent part of all entrepreneurial processes, it becomes somewhat hypocritical to retreat to the 'high grounds of academia' (Schon, 1995) when these challenges manifest in scholarly pursuits. Challenging research is exactly what is required for interestingness in entrepreneurship research (Landstrom et al., 2016). Real-time projects and their recorded failures offer unique insights on entrepreneurial failure, especially given that selective recall and hindsight bias become minimised. Accordingly, academic panels must resist the temptation of judging the quality of 
IAR research projects by successful new venture outcomes only. Doing so will only return us to the old problem of bias which originates from picking winners with little insights on entrepreneurial failure.

\subsubsection{Navigating Challenges of Academic Politics \& Role Triplicity}

Another challenge with IAR relates to the politics of education and research. Researchers looking to advance academic careers often come up against entrenched worldviews that are powerful and less accommodating of the IAR approach. The politics of research continues well into the dissemination of research findings. Unfortunately, top-ranked entrepreneurship journals have traditionally favoured large positivist studies, which can prove challenging when the goal is to build a career in academia through doctoral research. By pioneering IAR in entrepreneurship studies, it appears the challenge of role duality becomes that of role triplicity - i.e., managing the core project, thesis project and pioneering a methodology in a new context. However, we see positive changes with a growing number of influential voices calling for action design-based research and inclusivity in entrepreneurship scholarship (Leitch et al., 2010; Fayolle, 2013; Van Burg \& Romme, 2014; Nambisan, 2016; Landstrom et al., 2016; Berglund et al., 2019). The louder these voices get, the more opportunities it creates for dissemination and legitimisation of the IAR approach.

Similarly, entrepreneurship researchers may be discouraged from pursuing the IAR path, or at best, receive minimal support in this regard. As we experienced in Case 1, there were research development workshops on qualitative research that outrightly discouraged the use of action research. With the lack of support, researchers may either feel lost or be driven to choose conventional and predictable research methods. Our experience in Case 1 reveals that this is often based on either a preconceived misunderstanding of action research or a superficial understanding of the methodology by its critics. When we probed deeper, it soon became evident that the idea that action research is a family of practices (Reason \& Bradbury, 2008) 
has not sunk in. Often, one modality of action research is either assumed to be 'true-for-all' or is believed to be 'the only way of doing action research'. Our experience shows that some scholars who may be sympathetic to action research, often had doubts about our IAR approach. Further dialogue revealed that they assumed participatory action research (PAR) to be the only acceptable way of doing action research. We believe this relates to the close similarities PAR has with ethnography and more widely accepted 'normal science' methodologies (Argyris \& Schon, 1989). By gently educating our critics or doubters in our IAR approach, we get one of the following reactions: 'interesting approach', 'risky approach', 'never heard of this approach' or simply, 'I didn't realise you could do action research this way'. Hence, the entrepreneurship doctoral researcher using IAR is served with a challenge of research and gently educating their audiences about the methodology - hence, role triplicity.

However, the solution may reside in building resilience by honestly articulating selfdevelopment needs at the pre-step of research and determining the degree to which it might offer motivational sustenance throughout the IAR process. We are not naïve to think that such clarity is always possible at the start of research projects. However, one thing is clear. The motivation for pursuing this path must be intrinsic and go beyond simply obtaining a doctorate for the purpose of getting a job in academia. Researchers must remember that IAR develops capabilities which render them valuable in multiple roles. This is particularly true of Case 1, as captured by his reflective excerpt at the end of the research project:

\footnotetext{
...going forward, I see myself filling multiple roles as a scholar-practitioner. As a digital entrepreneurship educator, I hope to continue passing on valuable insights from my research to students of business and entrepreneurship. More importantly, I hope to make significant contributions to practice-based entrepreneurship education. Likewise, through two 'Best Paper' awards and journal publications, I have learned that the same capabilities which drive entrepreneurial performance can be transferred into a research context, delivering similar results. Thus, my confidence as a researcher has also grown. As such, I hope to continue conducting research and publishing findings that the wider community of entrepreneurship scholarship and practice find useful...in my role as a practitioner, I look forward to offering valuable counsel which assists in nurturing the growth of pure digital new ventures. I suppose the challenge, therefore, is to determine how best to balance the multiple roles based on new capabilities. Ultimately, I can attest to the truism of the assertion that 'all good research is for me, for us and for them' (Reason \& Marshall, 1987, p. 112).
} 
As research on entrepreneurial leadership suggests, persistence and patience is a desirable quality for success. It promotes resilience that ensures entrepreneurial survival. Survival has been strongly correlated with improved odds of arriving at venture scalability. This is also true for IAR. In Case 1, persistence eventually led to the leveraging of emergent solutions to advance the core project. Likewise, persistence ensured that the researcher finally discovered sympathetic audiences and deepened his knowledge of the politics of academic scholarship.

Ultimately, the cases reveal that an IAR approach is beneficial on multiple levels and entrepreneurship audiences may be more receptive to the approach than previously assumed. Indeed, while reflecting on the research process in hindsight, we arrived at the startling realisation that responses to our IAR research approach in Case 1 were overall highly positive than negative, but we tended to mentally exaggerate the negative responses, given the raw emotions they initially ignited. There were several open-minded and supportive academics at conferences who showed support for our approach and its innovativeness when they learned about it. Thus, doctoral researchers cannot afford to be consumed by the negative emotions that come with occasional rejection. Like entrepreneurs, they must forge ahead and stay motivated when it makes sense to do so and seek out the many supportive peers who may exist behind disciplinary silos. In our case, we learned a lot from the cross-pollination of ideas at action research conferences, with researchers from very different disciplinary backgrounds - nursing and health care, hospitality management, supply chain management, information systems management and others.

\subsection{Discussion \& CONCLUSION}

As our cases reveal, IAR achieves phenomenon-methodology fit, which presents an opportunity for meaningful scholarship on the entrepreneurial process. Such methodology fit is necessary for addressing several challenges facing the entrepreneurship discipline today. As the discipline matures and becomes institutionalised, it risks gearing research towards conventional 
methodologies with an emphasis on theory testing. Gearing research towards filling lesser and lesser gaps may satisfy the needs of academic stakeholders but adds very little to our understanding of the mechanisms that drive an entrepreneurial process (Davidsson, 2016). Scholarship based on theory testing, mainly results in the lack of applicative knowledge, as consistent with Aristotelian phronesis. Without applicative knowledge, practitioners and students of entrepreneurship are left to fend for themselves in the swampy lowlands of new venture creation, while scholars retreat to the high grounds of academia (Schon, 1987; Dimov, 2016). Therefore, the need for interestingness has been highlighted in the entrepreneurship discipline. Interestingness, as noted, involves conducting challenging scholarship through praxis, with a multi-stakeholder focus (Landstrom et al., 2016). Furthermore, controversies relating to entrepreneurship's distinctiveness as a bona fide discipline of scholarship persist. Hence, several scholars call for an 'entrepreneurial method' which is practice-based and explicit in merging the dynamic and emergent process of new venture creation with new knowledge production that benefits theory, practice and policy formulation (Bygrave, 2007; Sarasvathy \& Venkataraman, 2011). Both cases suggest that IAR is an entrepreneurial methodology, positioned to meet these challenges.

Consequently, we have developed a framework for integrating the methodology into various forms of entrepreneurship scholarship, in symbiotic relations of new venture creation, knowledge production and practice-based learning. As we have learned, the lack of such practical guidelines can impede the adoption of this approach. Hence, this paper adds value by offering an evidence-based framework that may be adapted to suit the needs of different contexts. Nevertheless, there are limitations and challenges to adopting this approach. Since the challenges of role duality may constrain what is physically possible to accomplish in an IAR study, researchers will often find it feasible to study one live case at a time. This limits the potential for simultaneous cross-case comparison which could deepen analysis. Given that our 
proposed framework was based on triangulating experiences in two cases of new venture creation, scholars should interpret insights from these cases as departure points for exploring the use of an IAR approach under various circumstances. The result could be context-specific adaptations of our proposed framework that further advances the use of this approach. By building a body of literature around the framework, future entrepreneurship scholars will be served with more cases that translate the use of this approach in different contexts.

Additionally, the short-term nature of academic scholarship may force researchers to place unnatural time frameworks on their studies. This time frame may not allow for a longerterm enactment and observation of entrepreneurial processes from nascent phases to maturity. For instance, the core project in Case 1, focused on the early phases of new venture creation and ended after its three-year delimitation. Nevertheless, it continues to generate insights well beyond the scope of the initial study. Under similar circumstances, we recommend that researchers interpret this limitation as an opportunity for further research on the subsequent phases of an entrepreneurial process. In our case, we envisage new research questions that seek answers to the vicissitudes involved in scaling digital new ventures. 


\subsection{REFERENCES}

Aldrich, H. E. (2014, August). The democratization of entrepreneurship? Hackers, makerspaces, and crowdfunding. In Annual Meeting of the Academy of Management.

Argyris, C. (1996). Actionable knowledge: Design causality in the service of consequential theory. The Journal of Applied Behavioral Science, 32(4), 390-406.

Argyris, C., \& Schön, D. A. (1989). Participatory action research and action science compared: A commentary. American behavioral scientist, 32(5), 612-623.

Baker, T., \& Nelson, R. E. (2005). Creating something from nothing: Resource construction through entrepreneurial bricolage. Administrative science quarterly, 50(3), 329-366.

Berglund, H., \& Korsgaard, S. (2017). Opportunities, time, and mechanisms in entrepreneurship: On the practical irrelevance of propensities. Academy of Management Review, 42(4), 730733.

Berglund, H., Dimov, D., \& Wennberg, K. (2018). Beyond bridging rigor and relevance: the threebody problem in entrepreneurship. Journal of Business Venturing Insights, 9, 87-91.

Bouchard, T. J. (1976). Field research methods: Interviewing, questionnaires, participant observation, systematic observation, unobtrusive measures. Handbook of industrial and organizational psychology, 1, 363 .

Brynjolfsson, E., \& McAfee, A. (2014). The second machine age: Work, progress, and prosperity in a time of brilliant technologies. WW Norton \& Company.

Bygrave, W. D. (2007). The entrepreneurship paradigm (I) revisited. Handbook of qualitative research methods in entrepreneurship, 17-48.

Coghlan, D. (2007). Insider action research: opportunities and challenges. Management Research News, 30(5), 335-343.

Coghlan, D. (2019). Doing action research in your own organization (5th ed.). Los Angeles: SAGE.

Coghlan, D., \& Shani, A. B. (2008). Insider action research: The dynamics of developing new capabilities. Handbook of action research, 643-655.

Corbett, A. C., \& Katz, J. A. (2012). Introduction: The action of entrepreneurs. In Entrepreneurial action (pp. ix-xix). Emerald Group Publishing Limited.

Davidsson, P. (2015). Entrepreneurial opportunities and the entrepreneurship nexus: A reconceptualization. Journal of Business Venturing, 30(5), 674-695.

Davidsson, P. (2016). Researching entrepreneurship: Conceptualization and Design (2nd ed.). New York: Springer. 
Davidsson, P., Gordon, S. R., \& Bergmann, H. (Eds.). (2011). Nascent entrepreneurship (No. 22, p. 608). Cheltenham: Edward Elgar.

Dimov, D. (2016). Toward a design science of entrepreneurship. In Models of start-up thinking and action: Theoretical, empirical and pedagogical approaches (pp. 1-31). Emerald Group Publishing Limited.

Edmondson, A. C., \& McManus, S. E. (2007). Methodological fit in management field research. Academy of management review, 32(4), 1246-1264.

Eikeland, O. (2006). Phronesis, Aristotle, and action research. International Journal of Action Research, 2(1), 5-53.

Ekbia, H. R. (2009). Digital artifacts as quasi-objects: Qualification, mediation, and materiality. Journal of the American Society for Information Science and Technology, 60(12), 2554-2566.

Fayolle, A. (2013). Personal views on the future of entrepreneurship education. Entrepreneurship \& Regional Development, 25(7-8), 692-701.

Fisher, G. (2012). Effectuation, causation, and bricolage: A behavioral comparison of emerging theories in entrepreneurship research. Entrepreneurship theory and practice, 36(5), 10191051.

Frank, H., \& Landström, H. (2016). What makes entrepreneurship research interesting? Reflections on strategies to overcome the rigour-relevance gap. Entrepreneurship \& Regional Development, 28(1-2), 51-75.

Heron, J., \& Reason, P. (2006). The practice of co-operative inquiry: Research 'with'rather than 'on'people. Handbook of action research, 2, 144-154.

Heron, J., \& Reason, P. (2008). Extending epistemology within a co-operative inquiry. The Sage handbook of action research: Participative inquiry and practice, 366-380.

Herr, K., \& Anderson, G. L. (2014). The action research dissertation: A guide for students and faculty. Sage publications.

Honig, B. (2004). Entrepreneurship education: Toward a model of contingency-based business planning. Academy of Management Learning \& Education, 3(3), 258-273.

Johannisson, B. (2011). Towards a practice theory of entrepreneuring. Small business economics, 36(2), 135-150.

Johannisson, B. (2018). Disclosing Entrepreneurship as Practice. Edward Elgar Publishing.

Johansson, A. W., \& Lindhult, E. (2008). Emancipation or workability? Critical versus pragmatic scientific orientation in action research. Action research, 6(1), 95-115. 
Kallinikos, J., Aaltonen, A., \& Marton, A. (2013). The Ambivalent Ontology of Digital Artifacts. Mis Quarterly, 37(2).

Landström, H., Parhankangas, A., Fayolle, A., \& Riot, P. (2016). Challenging entrepreneurship research. London: Routledge.

Leitch, C. M., Hill, F. M., \& Harrison, R. T. (2010). The philosophy and practice of interpretivist research in entrepreneurship: Quality, validation, and trust. Organizational Research Methods, 13(1), 67-84.

March, S. T., \& Smith, G. F. (1995). Design and natural science research on information technology. Decision support systems, 15(4), 251-266.

Marshall, J. (1999). Living life as inquiry. Systemic practice and action research, 12(2), 155-171.

McMullen, J. S., \& Dimov, D. (2013). Time and the entrepreneurial journey: The problems and promise of studying entrepreneurship as a process. Journal of Management Studies, 50(8), $1481-1512$.

McMullen, J. S., \& Shepherd, D. A. (2006). Entrepreneurial action and the role of uncertainty in the theory of the entrepreneur. Academy of Management review, 31(1), 132-152.

Nambisan, S. (2016). Digital Entrepreneurship: Toward a Digital Technology Perspective of Entrepreneurship. Entrepreneurship Theory and Practice.

Neck, H. M., \& Greene, P. G. (2011). Entrepreneurship education: known worlds and new frontiers. Journal of small business management, 49(1), 55-70.

Neck, H. M., Greene, P. G., \& Brush, C. G. (Eds.). (2014). Teaching entrepreneurship: A practicebased approach. Edward Elgar Publishing.

Nzembayie, K. F., Buckley, A. P., \& Cooney, T. (2019). Researching Pure Digital Entrepreneurship-A Multimethod Insider Action Research approach. Journal of Business Venturing Insights, 11, e00103.

Pittaway, L., \& Cope, J. (2007). Entrepreneurship education: A systematic review of the evidence. International small business journal, 25(5), 479-510.

Rasmussen, E. A., \& Sørheim, R. (2006). Action-based entrepreneurship education. Technovation, 26(2), 185-194.

Reason, P., \& Bradbury, H. (2008). The SAGE handbook of action research: Participative inquiry and practice. Los Angeles, CA: SAGE.

Reason, P., \& Marshall, J. (1987). Research as personal process. Appreciating Adult Learning. London: Kogan Page, 112-126. 
Ries, E. (2011). The lean startup: How today's entrepreneurs use continuous innovation to create radically successful businesses. Crown Books.

Roe, R. A. (2008). Time in applied psychology: The study of "what happens" rather than "what is". European Psychologist, 13(1), 37-52.

Sarasvathy, S. D., \& Venkataraman, S. (2011). Entrepreneurship as method: Open questions for an entrepreneurial future. Entrepreneurship theory and practice, 35(1), 113-135.

Schon, D. A. (1984). The Reflective Practitioner: How Professionals Think In Action (Vol. 5126). Basic Books.

Schön, D. A. (1987). Educating the reflective practitioner (p. 27). San Francisco: Jossey-Bass.

Schön, D. A. (1995). Knowing-in-action: The new scholarship requires a new epistemology. Change: The Magazine of Higher Learning, 27(6), 27-34.

Selden, P. D., \& Fletcher, D. E. (2015). The entrepreneurial journey as an emergent hierarchical system of artifact-creating processes. Journal of Business Venturing, 30(4), 603-615.

Shane, S., \& Venkataraman, S. (2000). The promise of entrepreneurship as a field of research. Academy of management review, 25(1), 217-226.

Shani, A. B., \& Pasmore, W. A. (1985). Organization inquiry: Towards a new model of the action research process. Contemporary Organization development: Current Thinking and Aplications, Scott, Foresman, Glenview, IL, 438-448.

Simon, H. A. (1996). The sciences of the artificial. MIT press.

Van Burg, E., \& Romme, A. G. L. (2014). Creating the future together: Toward a framework for research synthesis in entrepreneurship. Entrepreneurship Theory and Practice, 38(2), 369397.

Venkataraman, S., Sarasvathy, S. D., Dew, N., \& Forster, W. R. (2012). Reflections on the 2010 AMR decade award: Whither the promise? Moving forward with entrepreneurship as a science of the artificial. Academy of Management Review, 37(1), 21-33.

von Briel, F., Recker, J., \& Davidsson, P. (2018). Not all digital venture ideas are created equal: Implications for venture creation processes. The Journal of Strategic Information Systems.

Welter, F. (2011). Contextualizing entrepreneurship-conceptual challenges and ways forward. Entrepreneurship theory and Practice, 35(1), 165-184.

Wiklund, J., Davidsson, P., Audretsch, D. B., \& Karlsson, C. (2011). The future of entrepreneurship research. Entrepreneurship Theory and Practice, 35(1), 1-9.

Zuber-Skerritt, O., \& Perry, C. (2002). Action research within organisations and university thesis writing. The Learning Organization, 9(4), 171-179. 
Table 1. Brief Summary of Two Cases Insider-Acting Digital Entrepreneurship

\begin{tabular}{|c|c|c|}
\hline Attributes & Case 1 - PDE Study & Case 2- HDE \\
\hline Context & $\begin{array}{l}\text { A doctoral study spanning } 3 \text { years; holistic change } \\
\text { programme in the EdTech industry }\end{array}$ & $\begin{array}{l}\text { MBA dissertation spanning } 6 \text { months; limited } \\
\text { change programme in the Irish services sector }\end{array}$ \\
\hline $\begin{array}{l}\text { Research } \\
\text { Question, } \\
\text { Aim \& } \\
\text { Need }\end{array}$ & $\begin{array}{l}\text { Question: How can my self-aware actions in } \\
\text { leading digital new venture creation, contribute } \\
\text { towards knowledge of the digital entrepreneurial } \\
\text { process and the consequential mechanisms driving } \\
\text { emergence and performance? } \\
\text { Aim: To enact a PDE process in real-time and } \\
\text { theorise the mechanisms driving process at various } \\
\text { temporal phases. } \\
\text { Need: Primarily geared towards the production of } \\
3^{\text {rd }} \text { person knowledge for academic dissemination } \\
\text { and doctoral accreditation (for me, for us and for } \\
\text { them) }\end{array}$ & $\begin{array}{l}\text { Question: How can I lead the creation of a } \\
\text { scalable business model in my new venture? } \\
\text { Aim: To apply design models in a HDE startup } \\
\text { and determine the degree to which they help or } \\
\text { hurt the chances of creating a scalable hybrid } \\
\text { digital entrepreneurial new venture. } \\
\text { Need: Primarily geared towards learning that } \\
\text { produces } 1^{\text {st }} \text { and } 2^{\text {nd }} \text { person knowledge (i.e., for me } \\
\text { and for us) }\end{array}$ \\
\hline $\begin{array}{l}\text { Theoretical } \\
\text { lenses }\end{array}$ & $\begin{array}{l}\text { Entrepreneurial process - opportunity discovery \& } \\
\text { exploitation; effectuation \& bricolage; digital } \\
\text { entrepreneurship; digital technology theories } \\
\text { (technology affordances \& constraints, } \\
\text { sociomateriality etc.); cognitive theories of } \\
\text { entrepreneurial leadership; practitioner innovation } \\
\text { models (lean start-up \& design thinking) }\end{array}$ & $\begin{array}{l}\text { Entrepreneurial process \& new venture creation; } \\
\text { bricolage \& effectuation; practitioner innovation } \\
\text { models (lean start-up, design thinking); business } \\
\text { model innovation; cognitive and behavioural } \\
\text { models of digital entrepreneurial leadership }\end{array}$ \\
\hline $\begin{array}{l}\text { Core } \\
\text { Project \& } \\
\text { Outcomes }\end{array}$ & $\begin{array}{l}\text { Insider-act a pure digital new venture in } \\
\text { EdTech based on a new venture idea arising } \\
\text { from the researcher's practice as portfolio } \\
\text { digital entrepreneur in the EdTech industry } \\
\text { In the end, the new venture was deemed } \\
\text { scalable as judged by the increasing number of } \\
\text { natural users on the digital platform }\end{array}$ & $\begin{array}{l}\text { - Bricole the nascent phases of a new venture } \\
\text { idea in the Irish services sector while } \\
\text { focusing on opportunities to achieve venture } \\
\text { scalability prior to seeking capital investment } \\
\text { Leading a team of developers with varying } \\
\text { levels of commitment to new venture creation } \\
\text { was identified as a key challenge of } \\
\text { leadership } \\
\text { In the end, new venture creation project } \\
\text { stalled as team cohesion and resources } \\
\text { remained issues to be dealt with }\end{array}$ \\
\hline Time frame & From March 2016 - March 2019 & March 2019 - August 2019 \\
\hline $\begin{array}{l}\text { Outcome } \\
\text { focus }\end{array}$ & $\begin{array}{l}\text { 'Generalisable' knowledge within the context of } \\
\text { PDE }-3^{\text {rd }} \text {-person knowledge }\end{array}$ & $\begin{array}{l}\text { Self-development \& venture specific capabilities; } \\
\text { potentially 'generalisable' to other HDE contexts }\end{array}$ \\
\hline $\begin{array}{l}\text { Knowledge } \\
\text { \& Learning } \\
\text { Outcomes }\end{array}$ & $\begin{array}{l}\text { - Identification and explanation of the } \\
\text { consequential mechanisms driving pure digital } \\
\text { new venture emergence at various temporal } \\
\text { phases } \\
\text { - Creation of a pragmatic model of pure digital } \\
\text { new venture creation expanded to include } \\
\text { prescriptive steps for practitioners } \\
\text { Self-regulatory cognitive models } \\
\text { (metacognition, self-control \& persistence) } \\
\text { help explain successful leadership of loose } \\
\text { collectives in a PDE context } \\
\text { A redefinition of effectual co-creation in a } \\
\text { PDE context as 'piecemeal co-creation'. }\end{array}$ & $\begin{array}{l}\text { - Creation of a practitioner model for } \\
\text { considering the critical elements implicated in } \\
\text { achieving venture scalability based on } \\
\text { experiential and theoretical knowledge } \\
\text { - Self-regulatory cognitive models identified as } \\
\text { critical in leading a team of loosely } \\
\text { committed team members in new venture co- } \\
\text { creation } \\
\text { The limits of entrepreneurial bricolage and } \\
\text { practitioner innovation models such as the } \\
\text { lean start-up are evaluated. }\end{array}$ \\
\hline
\end{tabular}


